\title{
First valid record of Astacilla Cordiner, 1793 in Australia, with description of a new species (Crustacea: Isopoda: Arcturidae)
}

\author{
Rachael A. King \\ Museum Victoria, PO Box 666E, Melbourne, Vic. 3001, Australia, and Department of Zoology, \\ University of Melbourne, Parkville, Victoria 3052, Australia \\ Present Address: Southeastern Regional Taxonomic Center, Marine Resources Research Institute, \\ PO Box 12599, Charleston, SC 29422, USA. \\ kingr@mrd.dnr.state.sc.us

\begin{abstract}
A new species of arcturid isopod, Astacilla lewtonae, is described from Western Australia. Although other Australian species have been attributed previously to this genus, this is the first record for the genus as currently diagnosed.
\end{abstract}

\section{INTRODUCTION}

The Arcturidae Dana, 1849 are a specialised group of marine isopods, which use the anterior four pairs of pereopods as a setose filtering complex extending from a cylindrical body usually elevated above the substrate. The family belongs to the isopod suborder Valvifera, which has recently been restricted by Poore (2001) who removed many genera traditionally placed in it to other families, Antarcturidae Poore, 2001 in particular.

The first description of an Australian arcturid isopod was of Arcturus brevicomis Haswell, 1881 from New South Wales. The types of this species are lost but it is probably a species of Neastacilla. Further species of Arcturus were described from New South Wales by Whitelegge (1904), Arcturus alcicornis, $A$. dentatus, A. nodosus, A. serratulus, $A$ simplicissimus, the types of all of which are also lost. All probably belong in the Antarcturidae.

The first review of Australian arcturid taxa was that of Hale (1924), who examined many specimens and established the endemic genus Parastacilla for two very distinctive species. He also described two other species and placed them in Neastacilla Tattersall (Neastacilla algensis and Neastacilla deducta). In a further, more comprehensive, review Hale (1946) described five arcturid species from the Southern Hemisphere and placed them all in Astacilla (Astacilla attenuata, A. macilenta, A. sheardi and $A$. vicaria from Australia and $A$. fusiformis from New Zealand) arguing that the genus Neastacilla Tattersall was poorly differentiated from Astacilla and should not be recognised. Hale (1946) reexamined his two previously described Australian species, Neastacilla algensis Hale, 1924 and Neastacilla deducta Hale, 1924, moving both to Astacilla, and included Astacilla marionensis Beddard, 1886 and Astacilla kerguelensis Vanhöffen, 1914 from the Southern Ocean in his discussion.
Guiler (1949) was also reluctant to confirm the genus Neastacilla and described five new Tasmanian species of Astacilla (Astacilla monoseta, A. inaequispinosa, $A$. unicornis, $A$. derwenti, and $A$. oculata). Of these, only $A$. monoseta and $A$. inaequispinosa are currently valid species (Poore et al., 2002).

All southern Pacific species of Astacilla were removed to Neastacilla by Kussakin (1972) who published a new diagnosis of Neastacilla. A thorough review of 18 Australian species of Neastacilla (Lew Ton, 1980) concurred with Kussakin's conclusions, finding that Neastacilla was a valid Pacific genus clearly separated from Astacilla, which had no known representatives in Australia. So, until now the family has been represented in Australia by Amesopous Stebbing, 1905, Neastacilla Tattersall, 1921, and Parastacilla Hale, 1924, only the last being endemic (King, 2000; Poore et al., 2002)

Although Astacilla is almost certainly paraphyletic (King, 2001), a useful diagnosis can be written. Astacilla currently comprises 32 species distributed in the northern and central North Atlantic, Mediterranean, northern North Pacific, southern Africa, and in India (Table 1). The new species described here extends the range of the genus to the eastern Indian Ocean and is the first record from Australia.

Material is deposited in the Western Australian Museum, Perth (WAM) and Museum Victoria, Melbourne (NMV).

\section{SYSTEMATICS}

\section{Astacilla Cordiner, 1793}

Astacilla Cordiner, 1793. -Sars, 1897: 87. -Monod, 1970: 1127-1142. -Kensley, 1983: 163-164. 
Table 1 The species of Astacilla and their distributions.

Species Distribution

A. amblyura Stebbing, 1905

A. arietina Sars, 1882

A. axeli Castelló, 1992

A. bispinata (Menzies \& Kruczynski, 1983)

A. bocagei Nobre, 1903

A. bonnierii Stephensen, 1915

A. caeca Benedict, 1898

A. cinguicula Castelló \& Carballo, 2000

A. corniger (Stebbing, 1873)

Junior synonyms include: Antarcturus ornatus, Tattersall, 1913; Astacilla setosa Vanhöffen, 1914; Arcturopsis hirsutus Barnard, 1914;

Arcturopsis hirsutus subglaber Barnard, 1914.

A. cymodocea Menzies \& Glynn, 1968

A. depressa Castelló \& Poore, 1998

A. deshayesii Lucas, 1849

A. eminentia Kensley, 1984

A. gibbossa Pillai, 1954

A. glabrus (Benedict, 1898)

A. gorgonophila Monod, 1925

A. granulata (Sars, 1877)

A. intermedia (Goodsir, 1841)

A. laevis Castelló \& Poore, 1998

A. lauffi Menzies \& Frankberg, 1966

A. lasallae Paul \& Menzies, 1971

A. longicornis (Sowerby, 1805) Junior synonyms include: Leacia lacertosa Johnston, 1825; Leachia gracilis Goodsir, 1841; Arcturus deshayesii Lucas, 1849; Arcturus linearis Stebbing, 1878.

A. longispina (Kensley, 1978)

A. marna Kensley \& Schotte, 1994

A. mediterranea Koehler, 1911

A. monodi Tattersall, 1925

A. paucisetosa Castelló \& Caballo, 2000

A. pusilla (Sars, 1873)

A. serrata Nunomura, 1998

A. spinata (Menzies \& Kruczynzki, 1983) Junior synonym: A. regina Kensley, 1984; (Kensley \& Schotte, 1989).

A. tayronae Müller, 1993

A. tranquilla (Kensley, 1975)
Southern India (Pillai, 1963).

Norway, North Atlantic (Sars, 1897; Kussakin, 1982).

Western Mediterranean (Castelló, 1997).

Gulf of Mexico.

Portugal.

Straits of Gibraltar; Mediterranean.

North Atlantic (Richardson, 1905; Schultz, 1969; Kussakin, 1982).

Western Mediterranean.

South Africa (Barnard, 1914, 1920; Kensley, 1978, 1984).

Gulf of Mexico, Caribbean (Kensley \& Schotte, 1989).

western Mediterranean.

Europe

South Africa.

India (Pillai, 1963).

Bering Sea, north western Pacific Ocean (Richardson, 1899, 1905, 1909; Birstein, 1963; Schultz, 1969; Kussakin, 1982).

north Africa; Mediterranean.

eastern USA, United Kingdom, Norwegian Sea (Harger, 1880; Benedict, 1898; Richardson, 1905; Schultz, 1969; Kussakin, 1982). Junior synonym: Astacilla americana Harger, 1878.

United Kingdom, Scandinavia (Kussakin, 1982). Junior synonym: Arcturus affinis Sars, 1869.

western Mediterranean.

Texas; Georgia (Schultz, 1969; Clark \& Robertson, 1982).

Venezuela (Kensley \& Schotte, 1989).

United Kingdom; Scandinavia (Sars, 1897; Stephensen, 1948;

Gruner, 1965; Naylor, 1972; Kussakin, 1982).

South Africa (Kensley, 1978; Kensley, 1984).

Dominica.

Mediterranean (Barnard, 1920; Kensley, 1984; Kensley, 1978;

Kensley, 1984).

Mauritania.

Western Mediterranean.

Scandinavia (Sars, 1897; Kussakin, 1982).

Japan.

Belize, Barbados, St Lucia.

Columbia

South Africa (Kensley, 1978, 1984).

Species transferred to other genera:

A. anophthalmus Birstein, 1963

A. attentuata Hale, 1946

A. bacillus Barnard, 1920

A. califormica Boone, 1918

A. dilatata Richardson, 1909

A. dilatata Sars, 1882

A. diomedeae Benedict, 1898

A. estadoensis Schultz, 1981

A. falclandica Ohlin, 1901

A. fusiformis Hale, 1946
Arcturus.

Neastacilla.

Neastacilla.

Neastacilla.

preoccupied, replacement name: Neastacilla richardsonae.

type species of Arcturella.

Neastacilla.

Neastacilla.

type species of Neastacilla.

Neastacilla. 
Table 1 (cont.)

Species

A. giardi Bonnier, 1896

A. inaequispinosa Guiler, 1949

A. kerguelensis Vanhöffen, 1914

A. levis Thomson \& Anderton, 1921

A. macilenta Hale, 1946

A. magellanica Ohlin, 1901

A. marionensis Beddard, 1886

A. monoseta Guiler, 1949

A. polita Gurjanova, 1936

A. setosa Vanhöffen, 1914

A. sheardi Hale, 1946

A. vicaria Hale, 1946

Leachia gracilis Goodsir, 1841

L. granulata Sars, 1877

L. intermedia Goodsir, 1841

L. nodosa Dana, 1849

Leacia lacertosa Johnston, 1825
Distribution

Arcturopsis.
Neastacilla.
Neastacilla.
Neastacilla.
Neastacilla.
Neastacilla.
Neastacilla.
Neastacilla.
Neastacilla.
junior synonym of Astacilla corniger.
Neastacilla.
Neastacilla.
junior synonym of Astacilla longicornis.
Astacilla.
Astacilla.
Arcturella.
junior synonym of Astacilla intermedia.

\section{Type species}

Oniscus longicornis Sowerby, 1805, subsequent designation by Fowler, 1912 (ICZN, 1986: Opinion 1369).

\section{Diagnosis}

Body strongly geniculate between pereonites 4 and 5, cylindrical, with no dorsal ridge. Antenna 2 slender, 2 or 3 flagellar articles, flagellum ending with claw. Maxillipedal palp with all segments free, palp article 3 similar width as article 2 . Pereonite 4 elongate, male and female of similar length.

Pereopod 1 setose, with unguis (rarely without). Pereopods 2-4 present and functional as setose appendages, dactylus absent. Pereopods 2-4 cylindrical, held close to the mouthparts, able to extend past the mouthparts, setae in rows, setae as long as segment, flexion between the carpus and the propodus present. Pereopods 5-7 with 2 ungues, secondary unguis robust.

Penial plate narrow, apex simple. Male pleopod 1 with lateral notch, with 3 lateral setae, lateral setae of similar length. Male pleopod 2 with appendix masculina tapered, without ridge, distally not widened, straight, elongated.

Uropodal exopod present, 3 setae on inner ramus.

Female functional brood pouch majority made up of pereonite 4 (or 3 and 4). Oostegite 5 absent.

\section{Remarks}

The systematics of the genus Astacilla is currently unresolved, given the similarities of many species to those in the genera Arcturella and Neastacilla. In the past Astacilla has been successively defined by an elongate fifth pereonite (Bate \& Westwood, 1868), pereopod 1 with a claw, one pair of oostegites (Sars, 1897), and the loss of dactyls on pereopods 2 to 4 (Kussakin, 1972). Examination of several species of Astacilla has shown that these characters are variable and in the case of the number of oostegites, incorrect. The lack of known synapomorphic character states for many arcturid genera combined with the reluctance of many authors to examine the higher systematics of the genera has lead to much confusion within arcturid taxonomy and much debate (Nordenstam, 1933; Monod, 1970; Kussakin, 1972; Schultz, 1981; Menzies \& Kruczynski, 1983; Wägele, 1989; Brandt, 1991).

\section{Astacilla lewtonae sp. nov. \\ Figures 1-4}

\section{Material examined}

\section{Holotype}

Male, $7.3 \mathrm{~mm}$, Western Australia, between Dampier and Port Hedland, $19^{\circ} 03.00^{\prime} \mathrm{S} ; 119^{\circ} 00.00^{\prime} \mathrm{E}$, $80 \mathrm{~m}$, WHOI epibenthic sled, CSIRO division of Fisheries, 11 Dec 1982 (WAM C 32344 ).

\section{Paratypes}

Female, $6.0 \mathrm{~mm}$, Western Australia, between Dampier and Port Hedland, 19³7.00'S; $118^{\circ} 53.00^{\prime} \mathrm{E}$, $30 \mathrm{~m}$, WHOI epibenthic sled, CSIRO division of Fisheries, 3 Jun 1983 (WAM C 32345 ). 2 females; $7.0-7.5 \mathrm{~mm}, 19^{\circ} 28.40^{\prime} \mathrm{S} ; 118^{\circ} 55.10^{\prime} \mathrm{E}, 38 \mathrm{~m}$, WHOI epibenthic sled, CSIRO division of Fisheries, 25 Oct 1983 (WAM C 32346 ). Immature male, $5 \mathrm{~mm}$, 


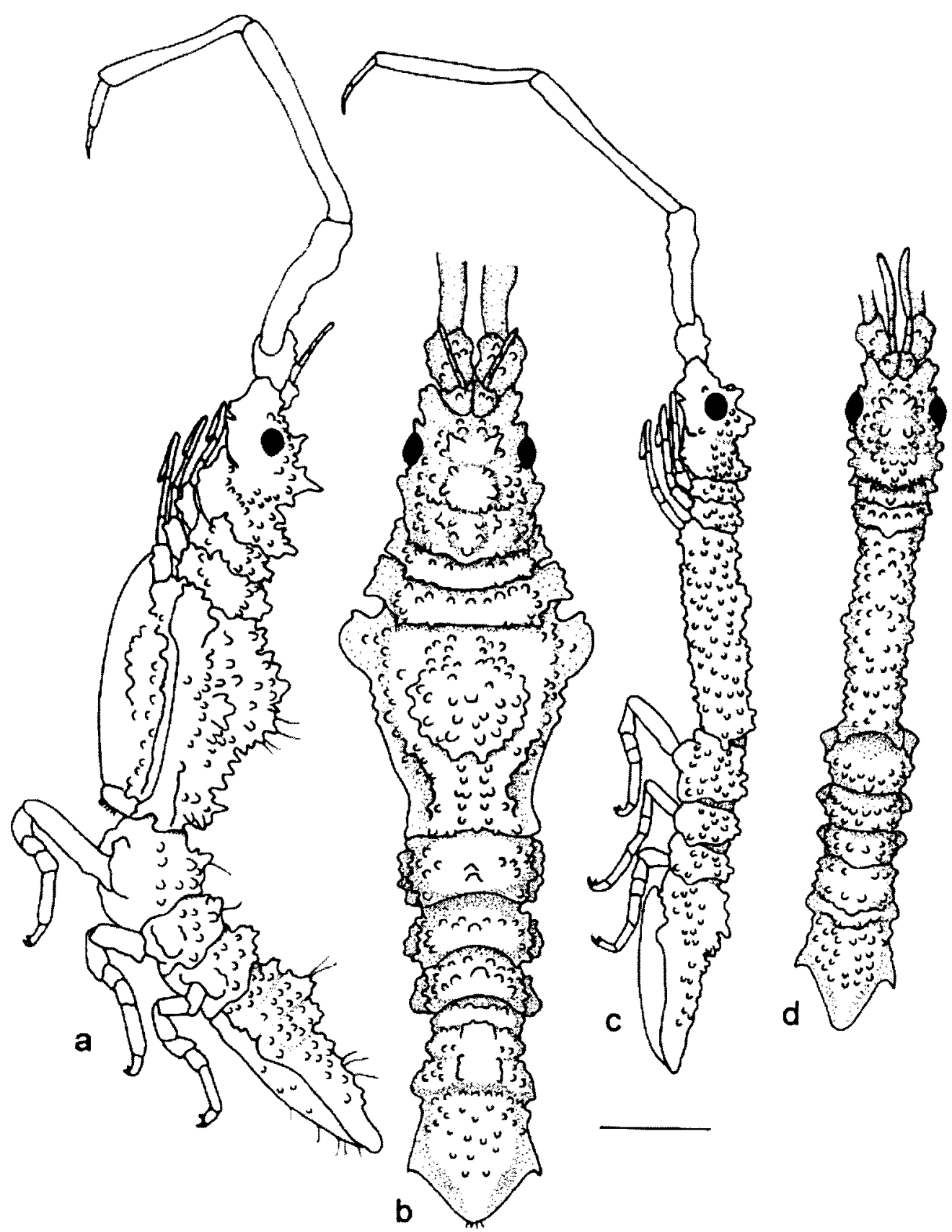

Figure 1 Astacilla lewtonae n.sp., female holotype (NMV J16900): a, lateral view; b, dorsal view. Male (NMV J16904): c, lateral view; $d$, dorsal view. Scale $=1.0 \mathrm{~mm}$.

$19^{\circ} 29.90^{\prime} \mathrm{S} ; 118^{\circ} 52.00^{\prime} \mathrm{E}, 37 \mathrm{~m}$, WHOI epibenthic sled, CSIRO division of Fisheries, 24 Oct 1983 (NMV J16651). Manca 2, $3 \mathrm{~mm}, 19^{\circ} 50.00^{\prime} \mathrm{S} ; 118^{\circ} 57.90^{\prime} \mathrm{E}, 84$ $\mathrm{m}$, WHOI epibenthic sled, CSIRO division of Fisheries, 29 Aug 1983 (NMV J16667). 3 females; 6.5-7.0 mm, $19^{\circ} 29.60^{\prime} \mathrm{S} ; 118^{\circ} 51.70^{\prime} \mathrm{E}, 40 \mathrm{~m}$, WHOI epibenthic sled, CSIRO division of Fisheries, 25 Oct 1983 (NMV J16648).

\section{Other material examined}

Northern Territory, North West end, Bommies, McCluer Island, $11^{\circ} 02.00^{\prime} \mathrm{S} ; 132^{\circ} 58.00^{\prime} \mathrm{E}, 8 \mathrm{~m}$, SCUBA, in sponges, Lowry, J.K., 16 Oct 1982 (NMV
J16582). $11^{\circ} 02.00^{\prime} \mathrm{S} ; 132^{\circ} 58.00^{\prime} \mathrm{E}, 8 \mathrm{~m}, \mathrm{SCUBA}$, in hydroids, Lowry, J.K., 16 Oct 1982 (NMV J16935).

South Australia, Spencer Gulf, Douglas Bank, $32^{\circ} 47.18^{\prime} \mathrm{S}$; $137^{\circ} 50.00^{\prime} \mathrm{E}, 15 \mathrm{~m}$, South Australia Fisheries, Aug 1986 (NMV J16917).

\section{Description}

Female

Body geniculate and cylindrical. Anterolateral margins of head sub-truncate with medial indentation, a small rostral point evident. Fusion of head and pereonite 1 indicated by dorsolateral groove incised laterally. Head heavily tuberculate, 
with 2 tuberculate dorsal elevations central and posterior to eyes, anterior tubercle with 2 apices. Pereonite 2 wider than pereonite 1, tuberculate with angular lateral margins extended. Pereonite 3 wider than pereonite 2 , tuberculate with angular lateral margins extended. Pereonite 4 about 6 times longer than pereonite 3 ; dorsally wider than pereonite 3 , tuberculate, angular lateral margins extended, with small posterior lateral extensions. Pereonites 5 to 7 progressively shorter posteriorly; heavily tuberculate, with lateral extensions. Pleon with evidence of three fused pleonites plus pleotelson; total length longer than combined lengths of pereonites 5 to 7 , with small anterior lateral wings, posterior angular lateral wings and rounded apex.

Eyes round, dorsolateral. Antenna 1 reaching past distal edge of second peduncular article of antenna 2; flagellum slender with aesthetascs attached distally. Antenna 2 slender, more than half as long as body; flagellum of 2 articles plus claw, lower margin without scales.
Maxilla 1 inner lobe with 3 terminai setae; outer lobe with 10 robust setae. Maxilla 2 inner lobe with 15 plumose setae; middle lobe with 4 setae; outer lobe with 3 setae. Maxillipedal endite with 10 mesial setae; palp article 2 and 3 with mesial setal rows; article 4 with mesial and lateral setal rows; article 5 with distal setae.

Pereopod 1 propodus smaller than carpus; dactylus about twice as long as wide, bearing unguis, which is longer than dactylus. Pereopods 24 merus to propodus with paired rows of long setae; dactylus absent; flexion between carpus and propodus present.

Pereopods 5 to 7 progressively shorter; dactylus denticulate, unguis present with secondary unguis $2 / 3$ length of primary unguis.

Uropod exopod not reaching mid point of endopod, with 2 setae of subequal length.

Oostegites present on pereopods 1 to 4 ; oostegite 4 thickened, with transverse suture delimiting posterior lobe.

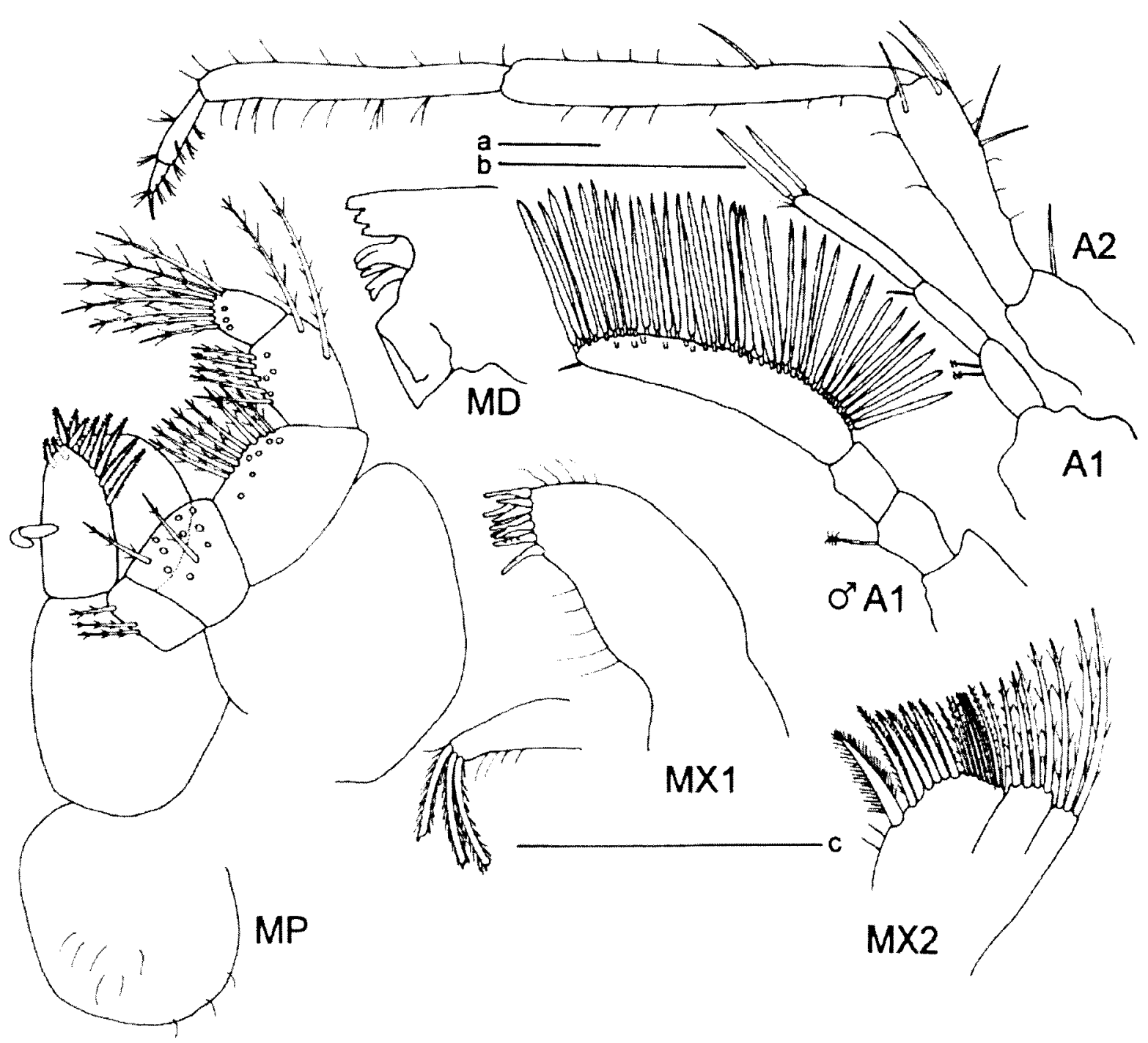

Figure 2 Astacilla lewtonae n.sp., female holotype (NMV J16900): left maxilliped; left maxillae 1 and 2; left mandible; antennae 1 and 2. Scales: $\mathrm{a}(\mathrm{A} 2)=0.5 \mathrm{~mm} ; \mathrm{b}(\mathrm{A} 1, \delta \mathrm{A} 1)=0.5 \mathrm{~mm} ; \mathrm{c}(\mathrm{MP}, \mathrm{MX1}, \mathrm{MX} 2, \mathrm{MD})=0.5 \mathrm{~mm}$. 


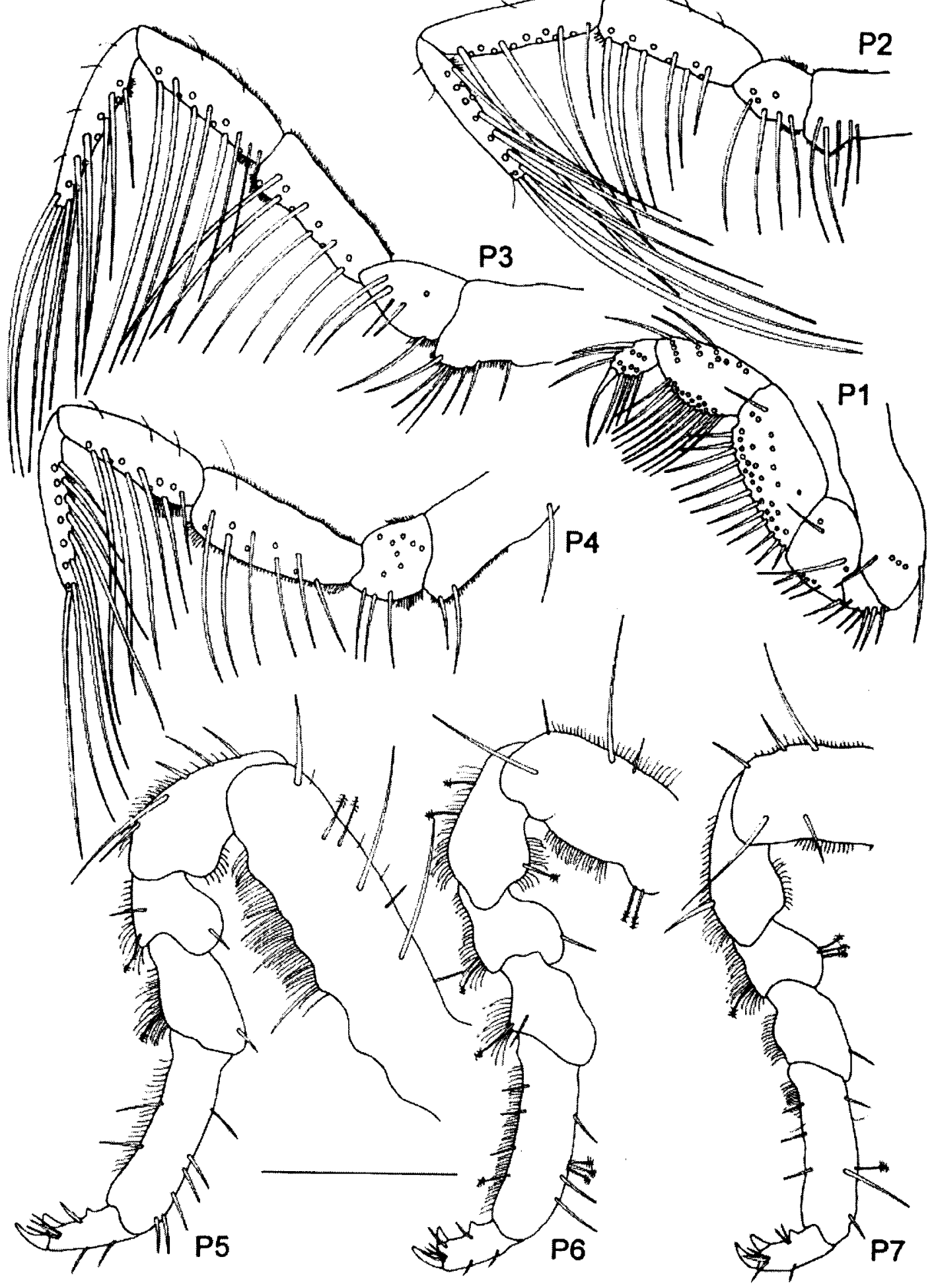

Figure 3 Astacilla lewtonae n.sp., female holotype (NMV J16900): pereopods 1 to 7 . Scale $=0.5 \mathrm{~mm}$.

Male

Body geniculate and cylindrical. Anterolateral lobes of head rounded with tuberculations, small rostral point evident. Head and pereonite 1 fused and with similar tuberculate ornamentation to female. Pereonite 2 and 3 tuberculate; lateral margins not greatly extended. Pereonite 4 around 8 times length of pereonite 3 , tuberculate, lateral margins not extended. Pereonites 5 to 7 tuberculate, anterolateral margins extended. Pleon length greater than combined lengths of pereonites 5 to 7 , evidence of 3 fused pleonites plus pleotelson, with small anterior lateral wings, angular posterior lateral wings and rounded apex.

Eyes round and dorsolateral. Antenna 1 extending past distal edge of second peduncular 
article of antenna 2; flagellum uniarticulate and with aesthetascs attached distally and laterally along the entire length. Antenna 2 as for female.

Mouthparts as for female.

Pereopods as for female.

Pleopod 1 exopod with lateral notch and 3 plumose setae of similar lengths on posterior face. Pleopod 2 with appendix masculina straight and extending twice the length of the endopod, tapering to two filaments. Penial plate straight and simple.

\section{Distribution}

Australia: Western Australia, Northern Territory, South Australia; 8 to 84 metres.

\section{Remarks}

Although morphologically similar to Australian Neastacilla species, the possession of a long, straight appendix masculina is the primary reason why this species belongs in Astacilla. Other characteristics that support the placement of this species within Astacilla are the possession of flexion between the carpus and propodus and the complete lack of dactyli on pereopods 2 to 4 , the presence of a dactylus on pereopod 1 and the shape of the female, which is widened and not especially elongate at pereonite 4 . The dorsal and lateral sculpture of the body of this species makes it unique among the Astacilla species.

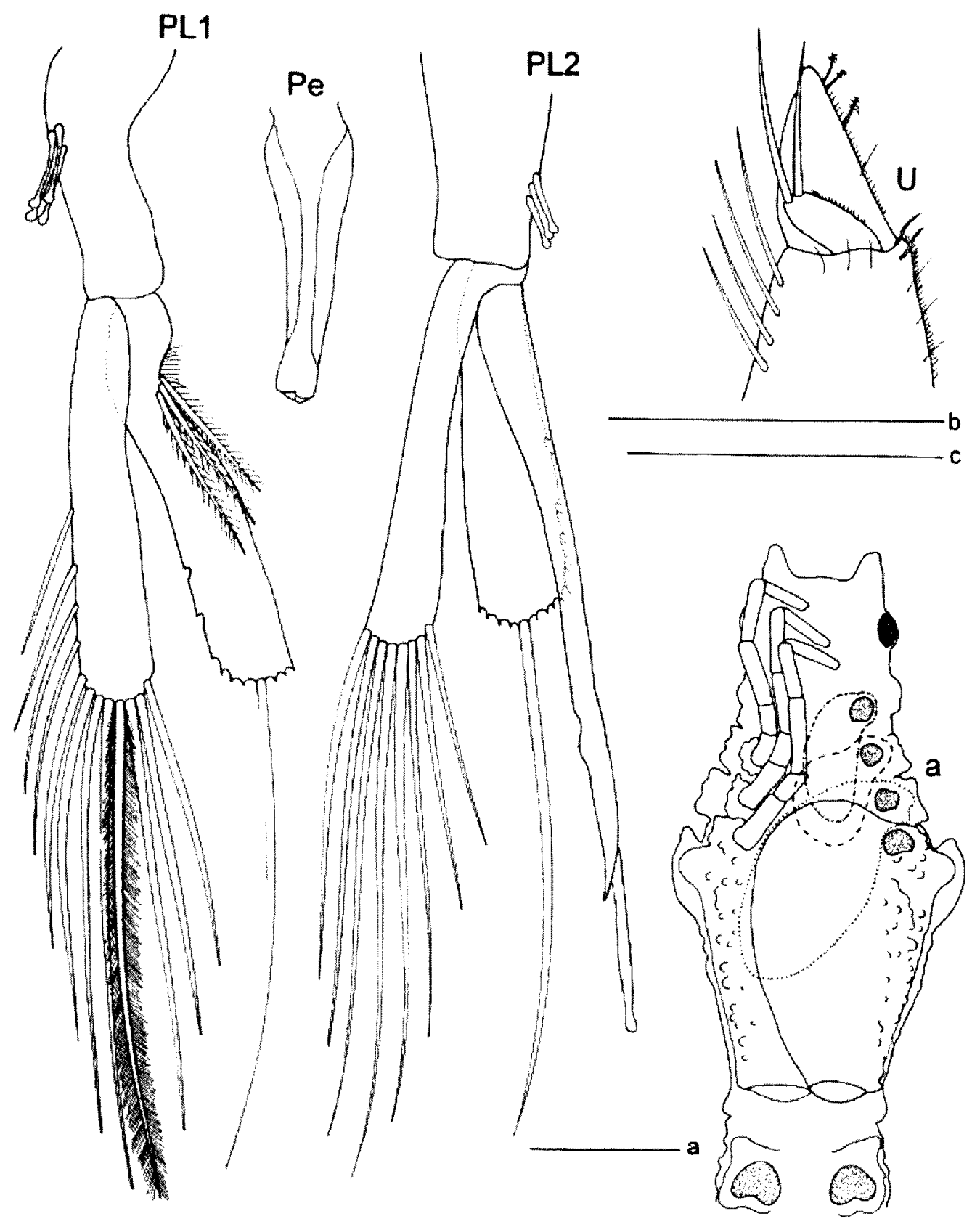

Figure 4 Astacilla lewtonae n.sp., male (NMV J16904): pleopods 1 and 2; penial plate. Female holotype (NMV J16900): distal end of uropod; a, ventral view with oostegites. Scales: $a(P L 1, P L 2, P e)=0.5 \mathrm{~mm} ; b(\mathrm{U})=0.5 \mathrm{~mm} ; \mathrm{c}(\mathrm{e})$ $=1.0 \mathrm{~mm}$. 


\section{Etymology}

This species is named for Helen Lew Ton who detected this 'strange' species in the collections of Museum Victoria.

\section{ACKNOWLEDGEMENTS}

This work was conducted as part of a postgraduate degree at the Zoology Department, University of Melbourne and Museum Victoria, funded by an Australian Postgraduate Award. I am grateful to Dr Gary Poore (Museum Victoria) for access to the collections, advice and encouragement and to Professor Alan Myers (University College Cork) for advice on the manuscript.

\section{REFERENCES}

Bate, C. S. and J. O. Westwood. (1868). A history of the British sessile-eyed Crustacea. Volume 2. John Van Voorst, London. 536 pp.

Beddard, F. E. (1886). Report on the Isopoda collected by HMS Challenger during the years 1873-76. Part 2. Report of the Voyage of HMS Challenger 17: 1-178.

Brandt, A. (1991). Zur Besiedlungsgeschichte des antarktishcen Schelfes am Beispiel der Isopoda (Crustacea, Malacostraca). Berichte zur Polarforschung 98: 1-240.

Cordiner, C. (1793). Remarkable ruins, and romantic prospects, of North Britain. With ancient monuments, and singular subjects of natural history. Peter Mazell, London. 96 plates with letterpress.

Dana, J. D. (1849). Conspectus crustaceorum quae in orbis terrarum circumnavigatione, Carolo Wilkes e classe Reipublicae, Foederate Duce, lexit et descripsit. American Journal of Sciences and Arts (2) 8: 424-428.

Guiler, E. R. (1949). New species of Astacilla from Tasmanian waters. Papers and Proceedings of the Royal Society of Tasmania 1948: 45-64.

Hale, H. M. (1924). Notes on Australian Crustacea. No. 3. Transactions of the Royal Society of South Australia 48: 209-225.

Hale, H. M. (1946). Isopoda - Valvifera. British, Australian and New Zealand Antarctic Research Expedition, 19291931. Reports-Series B (Zoology and Botany) 5: 161212.

Haswell, W. A. (1881). On some new Australian marine Isopoda - Part II. Proceedings of the Linnean Society of New South Wales 6: 181-196, pls 3, 4.

Kensley, B. (1983). Astacilla Cordiner, 1793 (Crustacea, Isopoda): proposed nomenclatural validation by use of plenary powers Z.N.(S.) 2319. Bulletin of Zoological Nomenclature 40: 163-164.

King, R. A. (2000). Rediagnosis of the endemic southern Australian genus Parastacilla Hale, 1924 (Crustacea: Isopoda: Arcturidae) with descriptions of two new species. Memoirs of the Museum of Victoria 58: 125-136

King, R. A. (2001). The systematics, evolution and biogeography of the Arcturidae (Crustacea, Isopoda). PhD thesis. University of Melbourne: Melbourne. 253 pp.
Kussakin, O. G. (1972). Isopoda from the coastal zone of the Kurile Islands. III. Three new arcturids from the Middle Kuriles with taxonomic remarks on the family Arcturidae. Crustaceana Supplement 3: 178-189.

Lew Ton, H. M. (1980). Reassessment of the genus Neastacilla Tattersall (Crustacea: Isopoda: Acrturidae) and a revision of the Australasian species. B.Sc. (Hons) thesis, Monash University, unpublished.

Menzies, R. J. and W. L. Kruczynski. (1983). Isopod Crustacea (exclusive of Epicaridea). Memoirs of the Hourglass Cruises 6: 1-126.

Monod, T. (1970). Sur quelques isopodes marins d'Australie I. Arcturidae. Bulletin du Muséum National d'Histoire Naturelle, Paris (2) 42: 1127-1142.

Nordenstam, A. (1933). Marine Isopoda of the families Serolidae, Idotheidae, Pseudidotheidae, Arcturidae, Parasellidae and Stenetriidae mainly from the South Atlantic. Further Zoological Results of the Swedish Antarctic Expedition, 1901-1903 3: 1-284, 2 pls, errata.

Poore, G. C. B. (2001). Isopoda Valvifera: diagnoses and relationships of the families. Journal of Crustacean Biology 21: 213-238.

Poore, G. C. B., Lew Ton, H. M. and Bardsley, T. M. (2002). Suborder Valvifera Sars, 1882. in: Houston, W.W.K., and Beesley, P. (eds) Zoological Catalogue of Australia.19.2a. Crustacea: Malacostraca: Syncarida, Peracarida: Isopoda, Tanaidacea, Mictacea, Thermosbaenacea, Spelaeogriphacea. CSIRO Publishing: Melbourne.

Sars, G. O. (1897). Parts 5, 6. Idotheidae, Arcturidae, Asellidae, Ianiridae, Munnidae. Pp. 81-116, pls 3348, In: An account of the Crustacea of Norway with short descriptions and figures of all the species. Vol. 2 Isopoda. Bergen Museum, Bergen.

Schultz, G. A. (1981). Arcturidae from the Antarctic and Southern Seas (Isopoda, Valvifera) Part I. Pp. 63-94 In: Biology of the Antarctic Seas 10. Antarctic Research Series. Vol. 32. American Geophysical Union.

Stebbing, T. R. R. (1905). Report on the Isopoda collected by Professor Herdman at Ceylon, in 1902. Report to the Government of Ceylon on the Pearl Oyster Fisheries of the Gulf of Manaar, Supplementary Report 4: 1-64, pls 61-12.

Sowerby, J. (1805). The British Miscellany, part 4. London.

Tattersall, W. M. (1921). Crustacea. Part VI. - Tanaidacea and Isopoda. British Antarctic "Terra Nova" Expedition, Natural History Reports, Zoology 3: 191-258, pls 191111.

Vanhöffen, E. (1914). Die Isopoden der Deutschen Südpolar Expedition 1901-1903. Deutsche Südpolar Expedition 1901-1903 25 (Zoologie) 7: 447-598.

Wägele, J. W. (1989). Evolution und phylogenetisches System der Isopoda. Stand der Forschung und neue Erkenntnisse. Zoologica (Stuttgart) 140: 1-262.

Whitelegge, T. (1904). Scientific results of the trawling expedition of H.M.C.S. "Thetis" off the coast of New South Wales in February and March, 1898. Crustacea. Part IV. Isopoda. Part III. Memoirs of the Australian Museum 4: 405-416.

Manuscript received 21 October 2002; accepted 2 April 2003 